\title{
BURKITT LYMPHOMA IN GASTROINTESTINAL TRACT: A REPORT OF TWO CASES
}

\author{
Aleksandar Čubranić ${ }^{1}$, Marin Golčić ${ }^{2}$, Dora Fučkar-Čupić ${ }^{3}$, Boris Brozović ${ }^{1}$, \\ Domagoj Gajski ${ }^{4}$ and Ivan Brumini ${ }^{5}$
}

${ }^{1}$ Department of Gastroenterology, Rijeka University Hospital Centre, Rijeka, Croatia; ${ }^{2}$ Department of Radiotherapy and Oncology, Rijeka University Hospital Centre, Rijeka, Croatia; ${ }^{3}$ Department of Pathology, Rijeka University Hospital Centre, Rijeka, Croatia; ${ }^{4}$ Department of Neurosurgery, Sestre milosrdnice University Hospital Centre, Zagreb, Croatia; ${ }^{5}$ University of Applied Health Sciences, Zagreb, Croatia

\begin{abstract}
SUMMARY - Burkitt lymphoma, a type of non-Hodgkin B-cell lymphoma, is the fastest growing human cancer, presenting pathologically with a 'starry sky' pattern. It is most often found in the abdomen and the jaw, however, localization in the abdomen other than the ileocecal area is very rare and described only in a handful of cases. Standard treatment consists of initial tumor cytoreduction followed by intense chemotherapy. Most of the relapses occur within one year of the diagnosis, while the 5-year survival is around $80 \%$. We present two cases which are specific for unusual location of Burkitt lymphoma in the colon and stomach, in immunocompetent patients with negative EpsteinBarr virus tests. Also, one of the patients presented is one of the oldest ever reported with abdominal Burkitt lymphoma, while the other patient is an example of diagnostic difficulties in distinguishing Burkitt lymphoma from similar lymphomas. Due to the rapidly growing tumors and urgent need for cytoreductive surgery, it is crucial to consider the diagnosis of Burkitt lymphoma even in atypical localizations or absence of the common risk factors associated with Burkitt lymphoma.
\end{abstract}

Key words: Burkitt lymphoma; Case reports; Colon; Cytoreduction surgical procedures

\section{Introduction}

Burkitt lymphoma (BL) is a type of non-Hodgkin B-cell lymphoma, found endemically in equatorial Africa and New Guinea in children infected with malaria and Epstein Barr virus (EBV), in immunocompromised patients, or as a sporadic form in Western countries $^{1}$. BL consists of uniform medium-sized Blymphocytes with basophilic cytoplasm, numerous mitoses, and apoptosis. Macrophages are scattered among tumor cells, giving BL a distinctive histologic appearance called "starry sky pattern".

Correspondence to: Aleksandar Čubranić, MD, Department of Gastroenterology, Rijeka University Hospital Centre, Krešimirova 42, HR-51000 Rijeka, Croatia

E-mail: acubrani@yahoo.com

Received March 7, 2018, accepted October 30, 2018
Tumor cells express membrane immunoglobulin (Ig) M, Ig light chain, B-cellular antigen, B-cell lymphoma (BCL) protein 6 , cluster of differentiation (CD) 10, 19, 20 and 22, while expressing negative results for CD 5, 23, and BCL 2. The most common cytogenetic change is $\mathrm{t}(8 ; 14)(\mathrm{q} 24 ; \mathrm{q} 32), \mathrm{t}(\mathrm{q} 11 ; \mathrm{q} 24)$ or $\mathrm{t}(8,22)(\mathrm{q} 24 ; \mathrm{q} 11)$ translocation. The proliferation index (Ki67) of BL is very high, usually over $95 \%$, so it is not surprising that $\mathrm{BL}$ is the fastest growing human cancer $^{3-5}$.

In adults, BL is most often found in the abdomen, followed by the jaw, while central nervous system disease is reported in up to $40 \%$ of patients. Localization other than the ileocecal area is very rare. BL can present as abdominal or jaw pain, melena, nausea, or even acute abdomen ${ }^{6,7}$, although the symptoms depend on the primary localization and spread of the tumor. 
Standard treatment consists of initial tumor cytoreduction followed by several cycles of intense chemotherapy based on high doses of cyclophosphamide, methotrexate, rituximab, and intrathecal application of cytostatics along with other necessary supportive medications ${ }^{8,9}$.

Relapses mostly occur within one year of the diagnosis, while the 5 -year survival is around $80 \%$. Around $10 \%-15 \%$ of patients die due to complications during treatment, while 5\%-10\% die from BL. Prognosis depends on patient age and spread of the disease. Adult patients with localized disease have a better prognosis than those with metastatic disease. On the other hand, children have a much better prognosis than adults, even in case of low stage disease ${ }^{10}$.

In the cases presented, appropriate informed consent was obtained, and we ensured everything to protect the patients' identity, respecting the highest ethical standards.

\section{Case 1}

A 73-year-old male Caucasian complained of hematochezia and symptoms of severe anemia. He had been operated for laryngeal cancer seven years before, without other oncologic treatment, and had a perforated gastric ulcer 19 years before; his previous medical history also included diabetes mellitus.

Esophagogastroduodenoscopy (EGDS) was performed following the work-up in the Emergency Department, but no recent signs of bleeding were found.

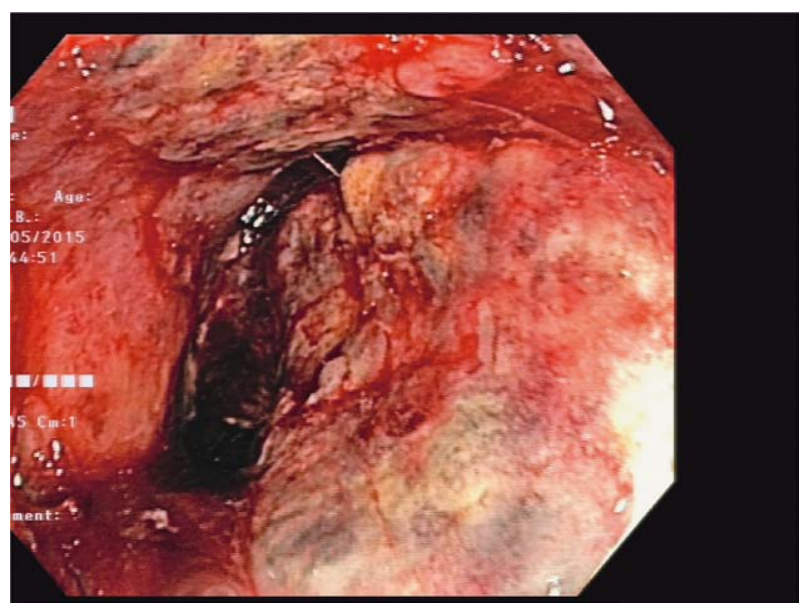

Fig. 1. Colonoscopy view of the tumor in the hepatic flexure.

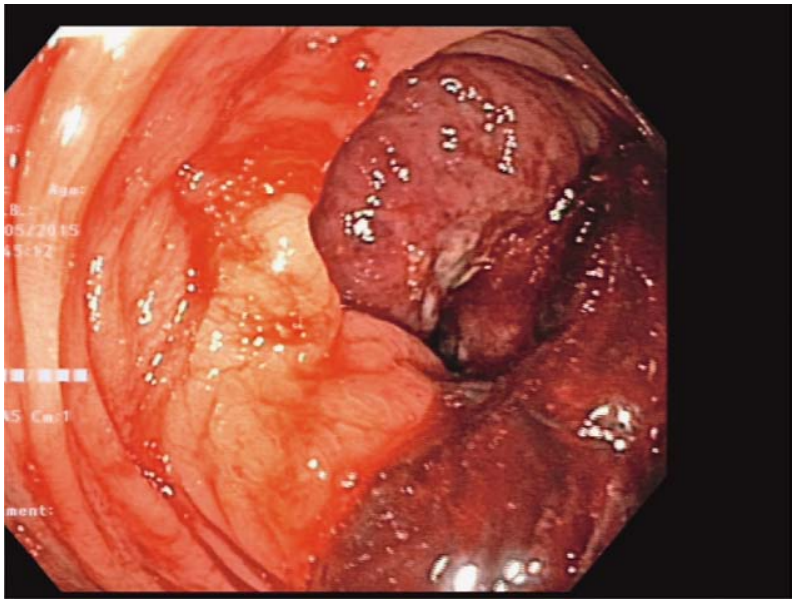

Fig. 2. Colonoscopy view of the tumor in the hepatic flexure.

Colonoscopy followed, displaying a tumorous mass in the area of hepatic flexure of the colon (Figs. 1 and 2). The histopathologic diagnosis was BL (Fig. 3). Immunohistochemically, tumor cells were negative for panCK, chromogranin, synaptophysin and $\mathrm{CD} 5$, and positive for LCA and CD20, with Ki67 over 95\%.

For staging purposes, multi-slice computed tomography (MSCT) of the abdomen was performed, showing a sizeable neoplastic process of hepatic flexure with regional lymphadenopathy. No other radiological abnormality was described. The case was presented to a multidisciplinary team for colorectal cancer, and a surgical procedure of right-sided hemi-

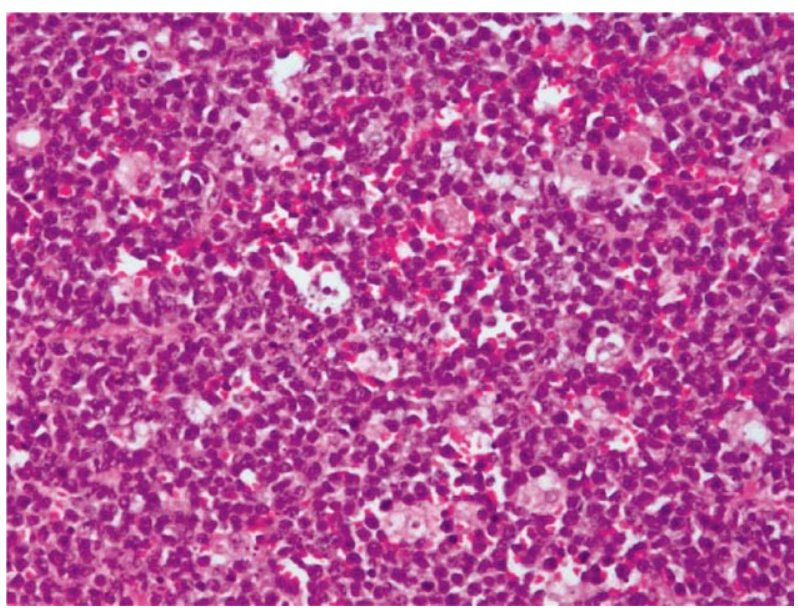

Fig. 3. Histology of Burkitt lymphoma found in the colon (HE, magnification X200). Histopathologic appearance of starry sky pattern: solid sheets of middle-sized atypical lymphocytes, with scattered macrophages. 
colectomy with latero-lateral (LL) anastomosis was suggested and later performed.

Adjuvant therapy consisted of EPOCH protocol along with palonosetron and other necessary supportive treatment.

\section{Case 2}

A 39-year-old male Caucasian started diagnostic procedure due to pain in the upper abdomen without any other symptoms. EGDS was performed to show a stomach mass and biopsy was done. There were seven biopsy specimens of $3 \mathrm{~mm}$ in size; histopathologically, these were gastric mucosal fragments infiltrated with dense atypical lymphocytes, with no starry sky mor-

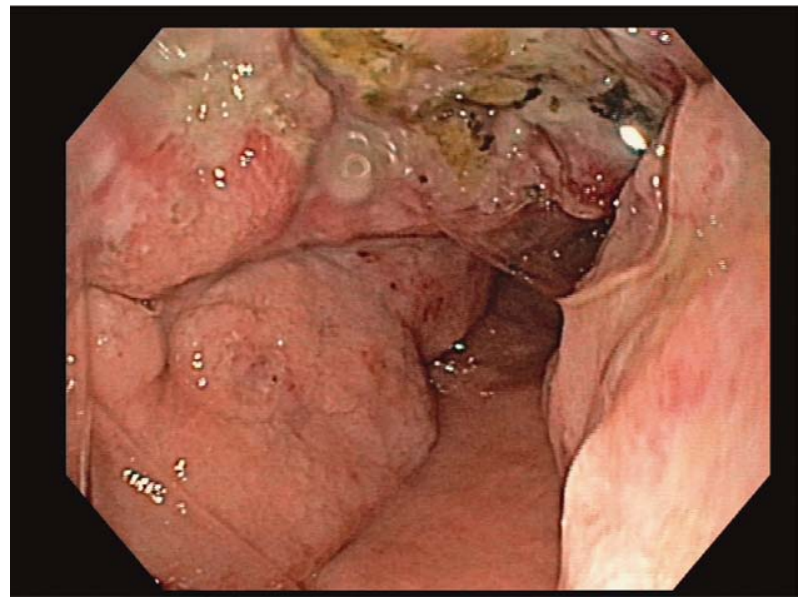

Fig. 4. Tumorous formation in the stomach as displayed on EGDS.

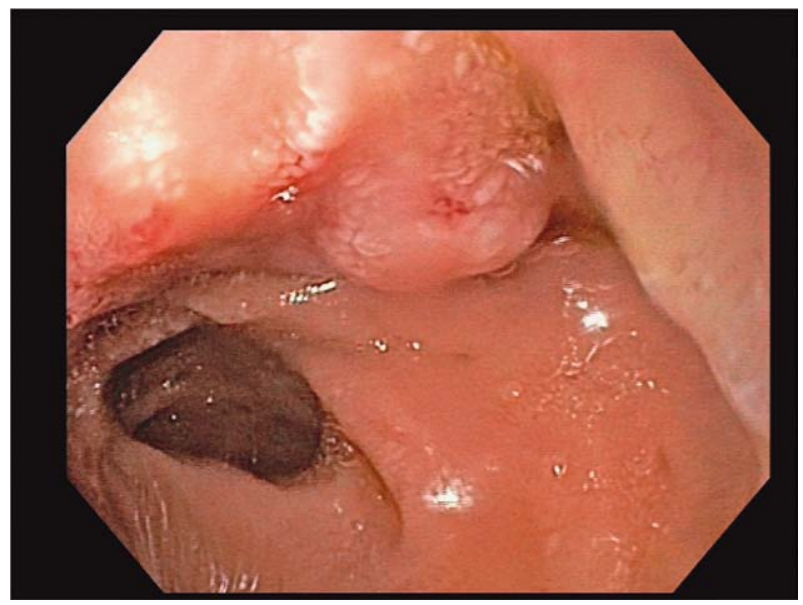

Fig. 5. Tumorous formation in the stomach as displayed on EGDS. phology. On immunohistochemical analysis, tumor cells were CD20+, CD10+, Bcl6+, cyclinD1-, and nearly $90 \%$ Ki67 positive. The histopathologic diagnosis was non-Hodgkin lymphoma, diffuse large B-cell lymphoma, not otherwise specified (DLBCL NOS), with the origin most likely from the germinative center. No further cytogenetic analysis was performed, and an R-CHOP chemotherapy protocol was applied.

Two months later, the patient was hospitalized as an emergency due to melena. EGDS was performed again to show an exulcerated tumor mass (Figs. 4 and 5). Thorax CT scan confirmed disease progression with enlarged regional lymph nodes and intratumoral necrosis despite therapy. On multidisciplinary team consultation, operative treatment was suggested. The

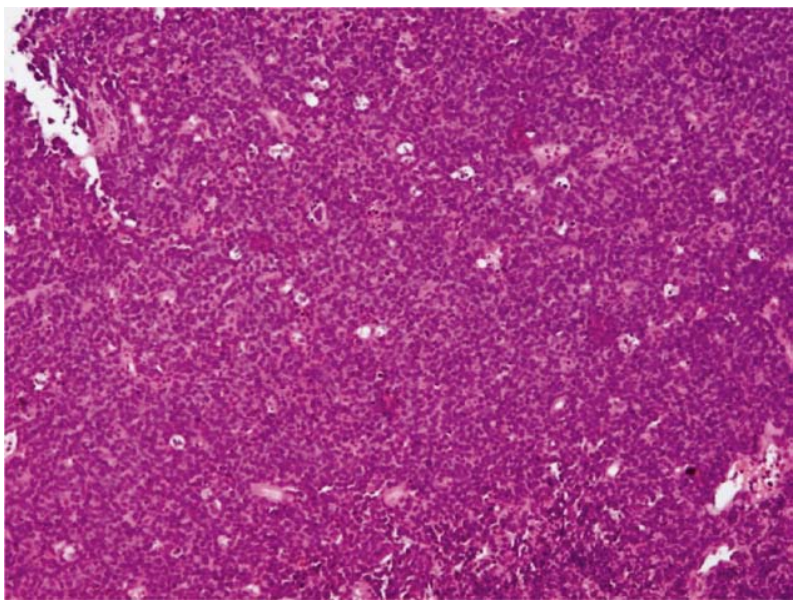

Fig. 6. Histology of Burkitt lymphoma found in the stomach (HE, magnification X200): starry sky pattern.

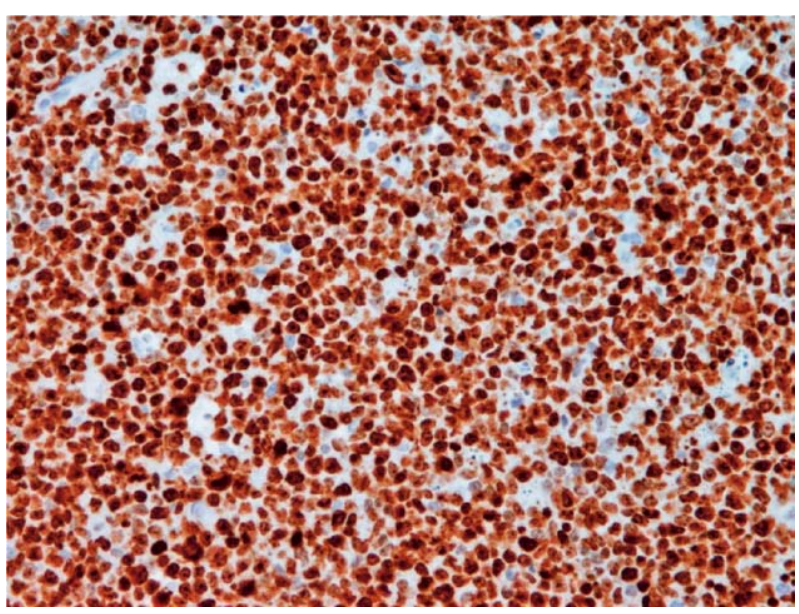

Fig. 7. Ki67 positivity of 100\% tumor cells (magnification X200). 
preoperative process was complicated with secondary obstructive cholangitis due to tumor compression.

Finally, gastrectomy with regional lymphadenectomy, omentectomy and cholecystectomy was performed. On gross pathologic examination, the stomach, the surrounding fat tissue with lymph nodes and the gallbladder wall were infiltrated by tumor tissue. Morphologically, the tumor consisted of monomorphic medium-sized atypical lymphatic cells with scant basophilic cytoplasm, round nuclei with multiple nucleoli, with numerous mitoses and apoptotic cells and with starry sky appearance (Fig. 6). Immunohistochemically, tumor cells were positive for CD20, CD10 and Bcl6, and almost negative for Bcl2. Ki67 was 100\% (Fig. 7).

Since the morphology and proliferation rate were not the same as on the small endoscopic biopsy, and there was rapid tumor progression despite the therapy administered, the diagnosis was changed to BL.

After the patient had stabilized, a prephase with GMALL protocol was suggested. Unfortunately, the patient died in another hospital before starting the treatment.

\section{Discussion}

Adult sporadic BL is commonly a disease of young male adults in their twenties and thirties. Both of our patients were male, but the first patient was much older than expected for BL. Both patients presented with sporadic BL, not associated with immunocompromised status (HIV negative) and EBV infection, which was also unexpected. Tumor localization in the hepatic flexure (case 1) and stomach (case 2) is not a typical manifestation of the disease either, described only in a handful of cases ${ }^{11,12}$. Hence, both of our cases serve to emphasize the fact that old age, along with gastrointestinal localization, does not exclude the possibility of $\mathrm{BL}$ and should be a viable differential diagnosis for high-grade non-Hodgkin lymphoma even in patients older than 70 years.

The main challenge in diagnosing $\mathrm{BL}$ is distinction between BL and diffuse large B-cell lymphoma, which is difficult. Distinguishing between these two lymphomas, however, is critical, especially in adults, as the two diseases are treated differently ${ }^{3,13,14}$. Our second case report serves to stress the problem with distinction between the two types of lymphomas. When atypical age or localization might point to diffuse large B-cell lymphoma, we still need to be wary of the possibility of $\mathrm{BL}$, and dubious cases should undergo genetic testing and additional analysis.

Early diagnosis of BL is also essential to prevent life-threatening complications that occur due to high tumor burden and fast increase in size. The second case is a blatant example of the former, with two lifethreatening gastrointestinal complications occurring in quick succession, gastrointestinal bleeding and secondary cholangitis after lymph node induced bile duct compression.

With the advancement of medicine and longer survival, it is necessary to consider that BL will appear more often in atypical localization or age group, even without typical risk factors associated with the disease. These case reports emphasize the importance of clinicopathologic correlation in the diagnosis of highgrade lymphomas in everyday practice.

\section{References}

1. Burkitt D. A "tumour safari" in east and central Africa. Br J Cancer. 1962;16:379-86. PMID 14017063

2. Fujita S, Buziba N, Kumatori A, Senba M, Yamaguchi A, Toriyama K. Early stage of Epstein-Barr virus lytic infection leading to the "starry sky" pattern formation in endemic Burkitt lymphoma. Arch Pathol Lab Med. 2004;128:549-52. Doi: 10.1043/1543-2165(2004)128<549:ESOEVL >2.0.CO;2

3. Nakamura N, Nakamine H, Tamaru J, Nakamura S, Yoshino T, Ohshima K, et al. The distinction between Burkitt lymphoma and diffuse large B-cell lymphoma with c-myc rearrangement. Mod Pathol. 2002 Jul;15(7):771-6.

Doi: 10.1097/01.MP.0000019577.73786.64

4. Chuang SS, Ye H, Du MQ, Lu CL, Dogan A, Hsieh PP, et al. Histopathology and immunohistochemistry in distinguishing Burkitt lymphoma from diffuse large B-cell lymphoma with very high proliferation index and with or without a starry-sky pattern: a comparative study with EBER and FISH. Am J Clin Pathol. 2007 Oct;128(4):558-64. Doi: 10.1309/EQJR3D3V0CCQGP04

5. Bertrand S, Berger R, Philip T, Bernheim A, Bryon PA, Bertoglio $\mathrm{J}$, et al. Variant translocation in a non-endemic case of Burkitt's lymphoma: $\mathrm{t}(8 ; 22)$ in an Epstein-Barr virus-negative tumour and in a derived cell line. Eur J Cancer. 1981;17: 577-84. PMID: 6271555

6. Mwanda OW. Clinical characteristics of Burkitt's lymphoma seen in Kenyan patients. East Afr Med J. 2004 Aug;(8 Suppl): S78-89. PMID: 15622606

7. Dunning K, Mattei P. Burkitt lymphoma presenting as colonic ischemia and overwhelming sepsis. J Pediatr Surg. 2007 Aug; 42(8):E15-7. Doi: 10.1016/j.jpedsurg.2007.05.002 
8. Molyneux EM, Rochford R, Griffin B, Newton R, Jackson G, Menon G, et al. Burkitt's lymphoma. Lancet. 2012 Mar 31; 379(9822):1234-44. doi: 10.1016/S0140-6736(11)61177-X. Epub 2012 Feb 13. Doi: 10.1016/S0140-6736(11)61177-X

9. Wildes TM, Farrington L, Yeung C, Harrington AM, Foyil $\mathrm{KV}$, Liu J, et al. Rituximab is associated with improved survival in Burkitt lymphoma: a retrospective analysis from two US academic medical centers. Ther Adv Hematol. 2014 Feb;5(1): 3-12. Doi: $10.1177 / 2040620713514682$

10. Kenkre VP, Stock W. Burkitt lymphoma/leukemia: improving prognosis. Clin Lymphoma Myeloma. 2009;9 Suppl 3:S231-8. Doi: 10.3816/CLM.2009.s.017

11. Ahluwalia M, Gotlieb V, Damerla V, Saif MW. Aggressive Burkitt-like lymphoma of colon in a patient with prior celiac disease. Yale J Biol Med. 2006 Dec;79(3-4):173-5. PMID: 17940628

12. Khaled M Musallam KM, Taher AT, Shamseddine AI. Burkitt's lymphoma of the colon and bronchi: three case reports. Cases J. 2008;1:15. Doi: 10.1186/1757-1626-1-15

13. Bellan C, Stefano L, Giulia de F, Rogena EA, Lorenzo L. Burkitt lymphoma versus diffuse large B-cell lymphoma: a practical approach. Hematol Oncol. 2009 Dec;27(4):182-5. Doi: $10.1002 /$ hon.914

14. Shahini L, Gašparov S, Petruševska G, Manxhuka Kerliu S, Veselaj F, Kurshumliu F, et al. Clinical significance of VEGF-A and microvessel density in diffuse large B-cell lymphoma and low-grade follicular lymphoma. Acta Clin Croat. 2017 Dec;56 (4):588-93. Doi: 10.20471/acc.2017.56.04.02

Sažetak

\title{
BURKITTOV LIMFOM U PROBAVNOM TRAKTU: PRIKAZ 2 SLUČAJA
}

\author{
A. Čubranić, M. Golčič, D. Fučkar-Čupić, B. Brozović, D. Gajski i I. Brumini
}

Burkittov limfom spada u non-Hodgkin B-stanične limfome te je najbrže rastući tumor u ljudi, a patološki se prezentira uzorkom 'zvjezdanog neba'. Najčešće je lokaliziran u trbuhu i u čeljusti, međutim, lokalizacija u trbuhu izvan ileocekalnog područja je izrazito rijetka i opisana samo u nekoliko slučajeva. Uobičajeno liječenje se sastoji od inicijalne citoredukcije tumora nakon čega slijedi intenzivna kemoterapija. Većina recidiva javi se unutar jedne godine od dijagnoze, dok je petogodišnje preživljenje oko $80 \%$. U članku prikazujemo dva slučaja koja su specifična zbog rijetke lokalizacije Burkittova limfoma u debelom crijevu i želudcu, u imunokompetentnih bolesnika s negativnim testom na Epstein-Barrov virus. Također, jedan od opisanih bolesnika je jedan od najstarijih slučajeva abdominalnog Burkittova limfoma opisanih u literaturi, dok slučaj drugog bolesnika naglašava izazove u dijagnostici Burkittova limfoma, osobito u bolesnika kod kojih se isti ne očekuje. S obzirom na brz rast tumora i hitnu potrebu citoreduktivne operacije važno je uzeti u obzir dijagnozu Burkittova limfoma čak i u bolesnika s netipičnom lokalizacijom tumora i bez uobičajnih rizičnih čimbenika povezanih s Burkittovim limfomom.

Ključne riječi: Burkittov limfom; Prikazi slučaja; Kolon; Citoredukcijski kirurški postupci 